\title{
New directions in Italian song lyrics?*
}

\section{The background}

The peculiar structure of contemporary Italian music lyrics originated a long time ago. ${ }^{1}$ Beginning in the $15^{\text {th }}$ century, a new kind of music came to Italy from Northern Europe, and particularly from France. Little is left of these melodies, which mostly belonged to the lowest musical traditions and thus left no written records. However, we can see some traces of evidence in the structure of the texts from this period, which sometimes are preserved and correspond to what is still today the usual configuration of Italian melodies: ${ }^{2}$ the prosody pattern of these texts is more regular and monotonous, and the lines are shorter and often end with words stressed on either the last syllable or the antepenultimate one. ${ }^{3}$

The situation was different prior to the $15^{\text {th }}$ century. During the Middle Ages (and still during the $16^{\text {th }}$ century for cultivated music), for example, a great many musical texts had a more ductile rhythm, which was provided, above all, by endecasillabi (11-syllable lines) and settenari (7-syllable lines). Moreover, the lines almost always ended with a word stressed on the penultimate syllable, which is by far the most common word ending in the Italian language. This kind of prosody can

\footnotetext{
* I would like to thank Andrea Bertolozzi for providing the musical scores and William McKiver and Elizabeth Elmi for helping with the English language revision.

1 This introduction is necessarily resumptive: a more detailed treatment, as well as additional bibliographic references, can be found in Zuliani (2009:7-82) to which it will be necessary to refer at times.

2 Most of these first preserved texts are laude of $15^{\text {th }}$ century, i.e. religious songs that use the melodies of ordinary secular songs that are, most of the time, lost.

3 A short description of this change is included, for instance, in the last revised edition of Beltrami's handbook (2011:138-42, stemming from Zuliani 2009:19-24, 113-51).
} 
still be found in the most conservative song traditions, such as the folkloric music of Tuscany and Latium.

As already mentioned, little is left of the music that caused the change in the prosody in the $15^{\text {th }}$ century. Furthermore, the rhythmic structure of ancient music is very hard to ascertain because it was not recorded through the writing system. But it is reasonably certain that that change was tied to the rise of modern tonal music, wherein the development of harmony was accompanied by a simplification of the rhythmic system. In fact, since then, melodies in standard Western music have been divided into bars, each one with a fixed length and with a rhythmic accent in a fixed position within the measure. ${ }^{4}$ This heightened regularity of the rhythmic patterns in the music requires more regularity in the rhythmic patterns of the words. Since melodies tend to end on an accented note (the tonic, which is perfectly static), many times the linguistic stress falls on the last syllable of verse as well. The same happens, although less frequently, with single musical phrases.

It is important to underscore that these musical structures are not well suited to the Italian language, wherein most of the words are long and paroxytone (i.e., stressed on the penultimate syllable) and the rhythmic structure is rather rigid. ${ }^{5}$ In English and French metrics, for example, this change in musical pattern had little or no real linguistic effect, while in Italian it ultimately caused the development of a set of new metrical rules and forms, which institutionalized the necessary changes. These new lyrical developments are called metri chiabreriani, after the poet Gabriello Chiabrera, whose contributions to Italian poetry in the late $16^{\text {th }}$ and early $17^{\text {th }}$ centuries were the most significant of all the authors who worked to develop this new style. ${ }^{6}$

These metres became part of the literary tradition during the $17^{\text {th }}$ century and are characteristic of arias in Italian melodrama. Thus, in a typical Italian opera, there are clear differences between the brief,

4 A treatment of this change from an ethnomusicological perspective can be found in Giannattasio (1998:105-27).

5 With regard to the rhythmical difficulties of Italian language in the metres of tonal music, see Bertinetto (1981:220-40); regarding the situation in modern popular music, see Giovannetti (2009).

6 The most important innovations are described infra. For a more detailed treatment, see, for instance, Beltrami (2011:391, 354-61) and Zuliani (2009:113-51). Regarding the characteristics of these metres in operatic music, see Fabbri (2007). 
cadenced verses of the arias and the slower, more fluctuating rhythm of the endecasillabi and settenari in the recitativi in which the line-endings are still primarily paroxytonic, a characteristic that was almost compulsory in Medieval lyric poetry. ${ }^{7}$

The rhythm of the recitativi is, therefore, the most apt to the Italian language since it follows a type of metre that was conceived when music, rather than conditioning or controlling the text, was mostly logogenic, as musicologists sometimes say. ${ }^{8}$ In short, the rhythm of the language in this metre provided a structural basis for the configuration of the music. On the contrary, in later musical traditions, the Italian language had to adapt to the new metres of the arias. An example of this is found in one of the most famous operatic arias, sung by Violetta in Verdi's Traviata:

1)

Ah, se ciò è ver, fuggitemi,

Solo amistade io v'offro:

Amar non so, né soffro

Un così eroico amor.

Io sono franca, ingenua;

Altra cercar dovete;

Non arduo troverete

Dimenticarmi allor. ${ }^{9}$

The rhyme scheme is typically asymmetrical within each strophe. The oxytone ending (the single-rhyme in English prosody) is the most difficult one to construct in Italian. As a result, it is used only in the final line of each strophe, where it is essential to the rhythm of the melody, and it rhymes with the final verse endings of all the other strophes. In this example, as often happens, the oxytone ending is obtained with an apocope (amor and allor instead of amore and allora). The apocope is not allowed in spoken language at the end of a sentence because standard Italian (like most of its dialectical varieties) has strong restrictions on consonant endings. These rules can be easily perceived in the typical Italian pronunciation of foreign words ending on consonants. The rhymes of the

7 For a survey of the few episodic exceptions, see Menichetti (1993:557-63).

8 See, for instance, La Via (2006:78).

9 La traviata, atto I, scena III (from Gronda / Fabbri 1997:729). 
first line of each strophe are proparoxytone: fuggitemi and ingénua have a stress on the antepenultimate syllable and cannot, in fact, be stressed on the last syllable as in the metrical prosody of English. The proparoxytonic words do not typically rhyme with other lines (differing from the rules of medieval lyric poetry which required verses to follow a strict rhyme scheme). In contrast, the endings of the second and third lines of each strophe are paroxytone, like the great majority of Italian words.

Other strong apocopes, along with literary forms and frequent inversions of standard word-order, allow for the text to be situated within the quick-paced, regular rhythm of the lines, which, in this case, are settenari of the melic kind. This type of verse is typical of operatic arias and has more restrictions with regard to word-stress disposition in comparison with the freer verse-structure used in traditional poetry. ${ }^{10}$

\section{The last decades}

This little example, chosen from a myriad of possibilities, already can demonstrate how these metric structures, influenced by melody, impose an artificial and often affected language on a given musical text. It is, in some ways, a paradoxical situation: Italian became the language of music across Europe, but it had to pay a high price to fit the rhythmic character of contemporary melodies. As often happens, this new kind of metre was accepted into the Italian literary canon, but when poetry began to strive for greater spontaneity, the price of metrical rigidity became too high. Consequently, these metres, along with the linguistic characteristics that allowed them to exist, were almost completely excluded from the canon by the end of the $19^{\text {th }}$ century. But in music, it was necessary to retain this more rigid system. In fact, all these metric forms and linguistic features remained typical of songs well into the $20^{\text {th }}$ century, marking again a separation between the language of music lyrics and that of everyday speech that could not survive the social changes of the 1960s and ' $70 \mathrm{~s} .{ }^{11}$

10 See e.g. Zucco (2001:39-43).

11 An overview of this transition can be found in Antonelli (2010:9-29), or Giovannetti (2011). 
A serious problem ensued after the 1960s because while anachronistic features in the language can be removed, it is more difficult to renounce metrical forms that are produced by melody. Since the ' 60 s, Italian lyricists have struggled with the divergence between the rhythm of the language and the rhythm of the music. ${ }^{12}$ The most important issue is the lack of oxytonic words, since modern linguistic sensibility does not allow for the use of unnatural apocopes that were indispensable to the proper functioning of these musical metres.

Before investigating the latest developments, however, it is necessary to briefly recapitulate the style that typifies modern pop-songs from the last decades of $20^{\text {th }}$ to the beginning of $21^{\text {st }}$ centuries, particularly at the lowest levels..$^{13}$ The most interesting feature comes at the line endings. As was previously stated, the apocopes and the literary forms which supplied oxytone rhymes are no longer possible, except when used as an archaism or out of irony. As a consequence, pop lyricists have developed a set of new oxytone rhyme-types, which can partially compensate for the loss:

- Proparoxytone words can rhyme with oxytone words through secondary stresses on last syllables, as in English: ${ }^{14}$

2)

Sincerità,

Adesso è tutto così semplice

Con te che sei l'unico complice

Di questa storia magicà. ${ }^{15}$

12 See, for instance, Antonelli (2010:33-48 and passim), as well as Zuliani (2009:4446, 57).

13 Once again, but for the last time, see the more extended treatment (with different exemples) in Zuliani (2009:32-43).

14 This kind of stress-beat mismatch can happen inside or at the beginning of the lines through all the Italian tradition: see e.g. Proto / Dell (2013:114-115) for similar mismatches in Italian folk songs (but not at the end of the lines, which is "is particularly averse to misalignments in Italian songs", Proto / Dell 2013:119).

15 This is the beginning of Sincerità, a song written by Giuseppe Anastasi, Maurizio Filardo and Giuseppe Mangiaracina, sung by Arisa, which won the "Newcomers" section of the Sanremo Music Festival in 2009 (included in the album Sincerità, Warner Music, 2009). 
The strong musical accent on the last syllable (which is only weakly stressed in the spoken language) can be seen in the score:

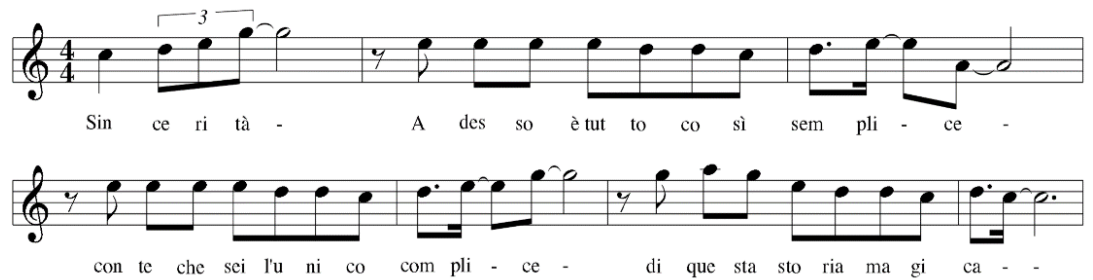

Fig. 1.

- The few monosyllables that are available in Italian (and that are, in fact, the most common class of oxytone words) are forcibly placed at the end of lines, even if they are useless exclamations (e.g. "sì!") or are typically atonic in standard language:

3)

Loro stanno chiusi ma

alla prima opportunità

salgon subito e la buttan dentro a noi. ${ }^{16}$

- English and French words are used to provide a stress at the end of lines; as a consequence, they are very common at the end of refrains, which frequently close on an accented note:

4)

Siamo qui a viverci

siamo noi cuori impavidi

è per te che farò

il mio love show. ${ }^{17}$

- Descending diphthongs (as in the word "noi") and so-called nessi vocalici (series of two separate vowels, as in "via") traditionally count

16 From La dura legge del goal, a pop-song written by Max Pezzali, Claudio Cecchetto, Marco Guarnerio and Pier Paolo Peroni, sung by the 883 (included in the album La dura legge del goal!, Fri Records, 1997).

17 From Love show (written by Luca and Diego Fainello), a very commercial popsong from the album Liberi da sempre (Sony BMG, 2008) of the boy-band Sonohra. 
as a single metrical syllable only inside Italian lines. In modern songs, however, they can count as oxytone rhymes at the end of lines (i.e., they can be sung on a single note) in contrast with previous Italian tradition. ${ }^{18}$ For example, an operatic aria cannot end with the last note sung on a diphthong, like in this pop-song:

5)

Io vorrei regalarti l'infinito che dà

Quel tenero abbraccio di un padre sognante

Che come un uomo volante,

Anche se tu non verrai,

Saprà nel cuore chi sei...

Io questo spero e vorrei. ${ }^{19}$

The playing of the diphthongs on single accented notes can be seen in the score (where the syncopation places the musical accents on the last eighth of the bar):
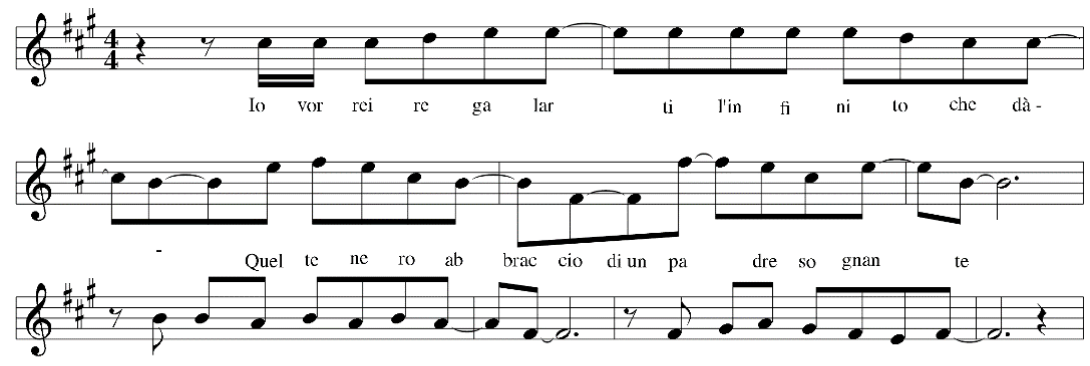

che co me un uo mo vo lan te an che se tu non ver rai

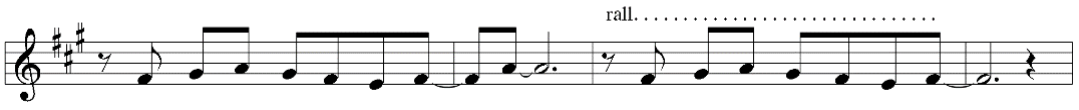

sa prà nel cuo re chi sei - io que sto spe ro e vor rei

Fig. 2.

18 Regarding the anomaly of this traditional rule, see Menichetti, "Storia della lingua e metrica. Tra fonetica e prosodia: 'i' vs iod", in Menichetti (2006:284-85). With regard to the change in musical metres, see Zuliani (2009:35-40) and Beltrami (2011:166-71).

19 These are the final lines of L'uomo volante (sung by Marco Masini and written by Marco Masini, Goffredo Orlandi and Giuseppe Dati, published by Universal Music in 2004), which won the Sanremo Music Festival in 2004. 
This anomalous use of diphthongs has been widespread in Italian song-lyrics since the second half of the $20^{\text {th }}$ century, while the others phenomenons are frequently perceived as belonging only to the style of trivial pop songs or canzonette. Consequently, in the last decades, these stratagems were uncommon in the songs of the so-called cantautori, the most refined songwriters.

\section{New developments}

For the purposes of this paper, I have done a survey of the most recent developments in the highest stylistic registers of Italian song writing. I examined recent music, looking for the works of new cantautori and, more generally, for songs in which the lyrics are particularly important. The first surprise was in finding lyrics like these (from a song by Baustelle):
6)
Ti ricordi noi
la sera in cui
le rondini
sopra la scuola
sopra la scuola
volavano per
proteggere $\mathrm{i}$
nostri blue jeans
dalle suoré
dai parrocì
sarà peccato
sarà reato
la prima volta
strapparsi gli slip..$^{20}$

20 From Love affair (written by Francesco Bianconi), one of the two singles from the album La moda del lento (MiMo/Venus 2003) of the "pop rock indie" band Baustelle. 
All the stratagems pertaining to the lowest register are used without restraint. In particular, the atonic monosyllables (articles, preposition, conjunctions, etc.) are sometimes put on the final stress of the lines in a way that upsets the usual prosody of the Italian language. The consequential fragmentation of text is so strong that most of the time internet transcriptions of these lyrics follow the syntax, rather than the enjambements by starting new lines at the end of each musical phrase. In addition, not only are proparoxytonic words accented on the last syllable of a verse (like rondinì and parroci), but even paroxytonic words receive a new accent at the end of the lines (like suoré), creating a strong violation of Italian prosodic rules. ${ }^{21}$ All this can be seen in the score (where again the musical accents are on the last eighth of the bar):
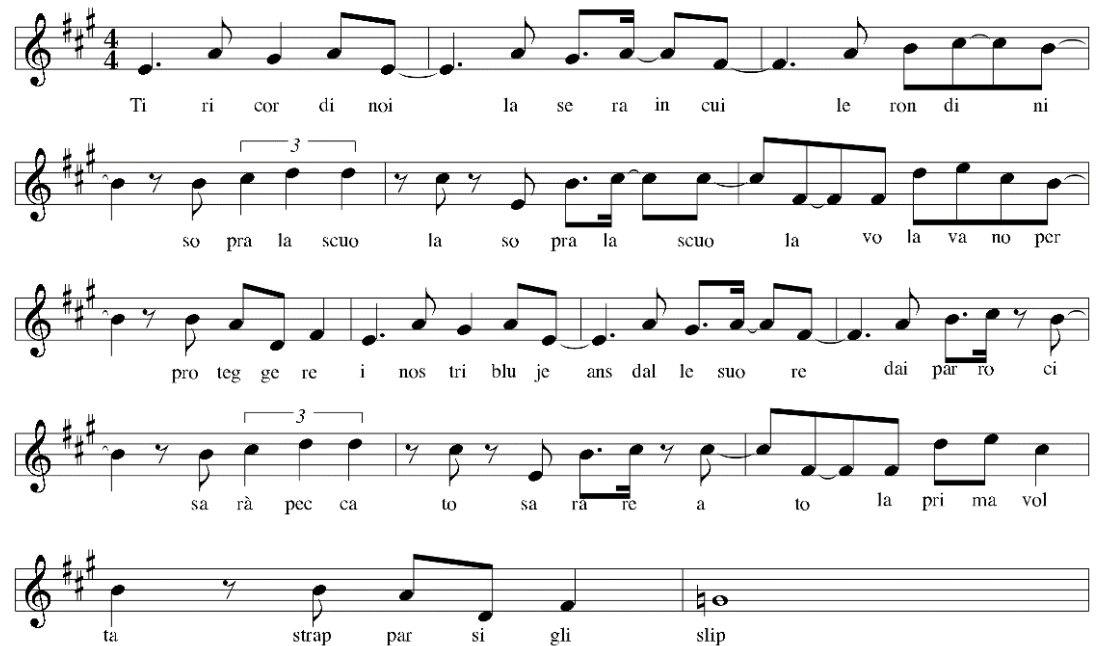

Fig. 3.

Paradoxically, this kind of song writing can be seen as an attempt to create a new distinctive language for music lyrics. The renunciation of traditional style creates a new artificiality, which is perhaps even stronger than the old one. And it is important to note that this is not the low

21 This kind of stress-beat mismatch, involving disyllabic paroxytones, can sometimes happen in Italian traditional songs, but only at the beginning and in the middle of the line; see Proto / Dell (2013:112). 
register of trivial pop songs. Indeed, in this example, as is typical of Baustelle songs, the syntax is ample and elaborate, and the meaning of the lines is subtle and complex.

In fact, the Baustelle ultimately take this process to the extreme, as in this refrain of Un romantico a Milano, where an essential word (amo) is given a new ostentatious accent (again on the last eighth of the bar) that would be absolutely impossible in spoken Italian at the end of a phonological phrase:

7)

Io vi amò,

vi amo ma vi odio però... 22

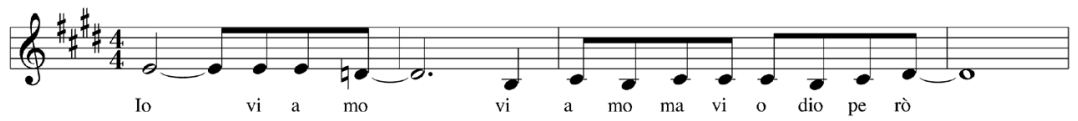

Fig. 4.

It is hard to ascertain whether or not these innovations will catch on. This is, most likely, just an isolated instance, which could even be perceived as elegant in a peculiar way. Surely these songs are much more cultivated than most other pop music ${ }^{23}$ and, consequently, these are extraordinary examples. Leaving aside these outliers, the survey shows a much less surprising situation. There is a new system of song writing that characterizes high-level lyrics, but that also, not surprisingly, is similar to the system of the lower level pop songs at the end of the $20^{\text {th }}$ century:

22 This is the beginning of the refrain of Un romantico a Milano (written by Francesco Bianconi), the second single from the album La malavita (Warner Music Italy, 2005).

23 In fact, one of the previously quoted examples is dedicated to the writer Luciano Bianciardi and has a video-clip inspired by Truffaut's Stolen Kisses. It even begins by stating "Between the Manzonis I prefer the real one: Piero" - a snobbish allusion that is probably inscrutable for the great majority of Italian youth: the writer Alessandro Manzoni is obviously well-known to most Italians beginning in elementary school, but just a few among the latest generations know of Piero Manzoni (1933-1963), an Italian conceptual artist. 
- no literary apocopes or other traditional devices, which were still occasionally used in previous decades;

- descending diphthongs and nessi vocalici can be used both as oxytone or paroxytone rhymes, as had already happened previously in pop songs;

- proparoxytone words can rhyme freely with oxytone words, which is the biggest difference with the previous high-level tradition (for example, "Poi mi regalerai un bacio lungo / Dall'Emilia all'Africà / Io ti darò un cesto di stelle di plasticà / E la mia povertà... la mia povertà" from Dente's Baby building ${ }^{24}$ ).

- atonic monosyllables at the end of lines are not widespread if they correspond to typically trivial pop-songs features (e.g. lines like "ma lo sai bene che / io amo solo te"), but are freely allowed if they belong to syntactically complex phrases (for example, "Allentare la presa per merito di / Chi mi consola ed esorta alla rinuncia" from Meganoidi's Zeta reticoli ${ }^{25}$ ).

Nevertheless, in conducting this survey I tried to look further into the so-called scena indipendente, which is something like indie or alternative music in Italy. A helpful source in this investigation was a recent book entitled Cosa volete sentire edited by Chiara Baffa for Minimum fax, which collects 13 short stories written by young Italian cantautori who are part of the scena indipendente. ${ }^{26}$ This research tool provided an important opportunity to find a good sample of musicians who like to experiment and test their own capabilities with words. The survey was then constructed based on their songs, not on their short stories, as well as on the songs of similar singers and bands. Through this process, an

24 From the album Non c'è due senza te, Jestrai Records, 2007. Dente is a cantautore born in 1976.

25 From the album Outside the Loop, Stupendo Sensation (Green Fog Records, 2003). Meganoidi is a ska-core and later a post-rock band.

26 See Baffa (2011). The cantautori in the book are: Andrea Appino (band: Zen Circus); Vasco Brondi, a.k.a. Le Luci della Centrale Elettrica; Dario Brunori (band: Brunori SAS); Letizia Cesarini, a.k.a. Maria Antonietta; Max Collini (band: Offlaga Disco Pax); Fabio De Min (band: Non Voglio Che Clara); Antonio Di Martino (band: Dimartino); Titano Gulmanelli (band: Jang Senato); Simone Lenzi(band: Virginiana Miller); Rossano Lo Mele (band: Perturbazione); Giuseppe Peveri a.k.a. Dente; Alessandro Raina (band: Amor Fou); Peppe Voltarelli. 
interesting trend emerged: in many of the songs, lyrics and melodies seem to renounce any regular and repetitive structure in a very peculiar way, and in particular they often renounce the most common melodic cadences. However, these results are distinct from spoken language because the rate of lyricism is usually quite high. These texts instead resemble free-metre poetry or, considering the way they are usually transcribed, some kind of lyric prose.

This direction is not new. Giuseppe Antonelli, for example, had already identified a similar trend a few years ago. ${ }^{27}$ He perceived a new style that tries to avoid oxytone endings, prefers long words and elaborate phrases, and that strives for the "subversion of connections between syntactic and musical phrases" through run-on sentences. Antonelli cited Carmen Consoli, Blue Vertigo, Tiro Mancino e Marlene Kuntz as examples of this new style. The survey conducted for this study shows that this new trend is becoming more marked, and in some ways quite different. With the singers mentioned by Antonelli the words were typically still manipulated in peculiar ways to fit the musical phrases. Yet, with the singers of the scena indipendente, language is given the upper hand. Sometimes the rhythms of ordinary speech prevail, but not in the same way as the recitative of the operatic tradition. Ultimately, these lyrics belong to the genre of rock, and thus we hear shouting and drums, along with catchy melodies that are often quite memorable.

The resulting lyrics are frequently transcribed without line divisions, as if they were written in prose. While their performance style and their lack of improvisatory affect may distinguish them from the verses of hip-hop, the looser formal style of that genre is still in some ways quite close. Rhymes are often incidental and irregular even if they are frequent, and they are often replaced by or combined with repetition of words or sounds. Indeed, poetic devices, such as anaphoras, anadiplosis, paronomasias, and alliterations, provide some of the recurring features that mark these songs as poetic texts.

There are many excellent examples of this phenomenon. Non voglio che clara, Amor fou, Maria Antonietta, Dimartino, Virginiana Miller and Le luci della centrale elettrica provide just a few out of numerous possibilites. One good example is the song Le guerre from Non voglio che Clara. The lyrics begin as follows:

27 Antonelli (2005). See also the final pages of Giovannetti (2011). 
8)

E non saranno le guerre quest'anno a farci paura, e non saranno gli scontri a tenerci distanti. e non saranno le sigarette ad ammalarci o gesù cristo che corra veloce a salvarci, ma saranno giorni spesi senza sconti, saranno giorni vuoti che non rendi, il tuo pensiero che non lascia scampo e tutto quello che ora vai perdendo. ${ }^{28}$

Another example is the following song, which is rather famous in Italy, from Le luci della centrale elettrica: ${ }^{29}$

9)

sventoleremo le nostre radiografie per non fraintenderci

ci disegneremo addosso dei giubbotti antiproiettile

costruiremo dei monumenti assurdi per i nostri amici scomparsi

vieni a vedere l'avanzata dei deserti

tutte le sere a bere

e per struccarti useranno delle nuvole cariche di piogge

vedrai che scopriremo delle altre americhe io e te

che licenzieranno altra gente dal call center

che ci fregano sempre che ci fregano sempre

che ci fregano sempre che ci fregano sempre ${ }^{30}$

Sometimes the rate of lyricism is lower and the manners of spoken language are more evident. This is the case in the song Saliva by the cantautrice Maria Antonietta, which begins:

10)

La nostra festa di ieri sera mi è piaciuta io mi sono divertita soltanto che adesso ho mal di testa e mi prendo un'aspirina secondo te cancellerà il sapore della tua saliva o il fatto che non ho capito un cazzo della vita? io stasera non esco saldamelo tu il conto con il resto del mondo io resto a letto perché mi sento uno schifo e non è la

28 From the album Dei cani (Sleeping Star, 2010). The lyrics are written by Fabio de Min, and the music is by the band. This quotation comes from the page $<$ http://www. rockit.it/articolo/17825/non-voglio-che-clara-dei-cani-i-testi> (10 July 2012), which published a preview of the lyrics and of the paintings in the booklet of the album.

29 This video had 875,121 hits on Youtube on 10 July 2012 (which is a large number for an Italian song).

30 These are the beginning lines of Cara catastrofe (written by Vasco Brondi), from the Album Per ora noi la chiameremo felicità (La Tempesta Dischi, 2010). The lyrics come from the official site (<http://www.leluci.net/index.php?id=224>, 10 July 2012). Giovannetti (2011:286) notes that some of the lyrics of Le luci della centrale elettrica were originally prose texts posted on a website. 
prima volta non è neanche la seconda che io mi sento uno schifo e non è la prima volta no non è la prima volta. ${ }^{31}$

Lyrics like these could be considered the fulfilment of a long-standing wish of many Italian cantautori to avoid the overly structured style of the canzonette, the most traditional and lowest level of song writing. Fabrizio De André, who is often considered the most important amongst the cantautori, talked often about this issue. He complained that fixed musical cadences as well as the lack of oxytone words prevented him from setting the prose outline that he prepared before composing his songs to verse. Indeed, at times these limitations could even force him to change the original meaning of the text. ${ }^{32}$ In songs like the ones above, the notorious oxytone cadences and the short, rhythmically monotonous lines are no longer needed. And yet, there is an inevitable price for this vast structural freedom: the victory of the language means the relinquishment of traditional cantabilità, that is, of the standard musicality typical of Italian melodies.

Looking at this issue from a broader perspective, it is not unusual that lyrics and melodies have tended to lose their repetitive structure. Evolution of this kind has always existed in music. For example, this could correspond to the greater freedom that distinguishes the refined Renaissance madrigal from the previous song tradition. Similarly, the cultivated evolution of German Lieder (i.e., the durchkomponiert Lied) has a freer structure in comparison with the more traditional volkstümliches Lied. The same kind of dismantling of traditional structures can be seen in Bebop or Free Jazz. It may seem strange to include contemporary independent or alternative rock and pop music amongst the most refined forms of musical production, but one must take into account

31 From the album Maria Antonietta (Picicca Dischi, 2012). The lyrics come from the web (e.g. $<$ http://allsongs.tv/video/musica-italiana/maria-antonietta-saliva-vid eo-ufficiale/> July 10, 2012), where they are always transcribed like prose.

32 "Scrivere canzoni in italiano è difficile tecnicamente, perché le esigenze della metrica ti rendono necessaria una gran quantità di parole tronche, che in italiano non ci sono, o comunque non abbondano. A questo punto ti vedi costretto, per garantire la qualità estetica del verso, a cambiare addirittura il senso di quello che vuoi dire", quoted in Coveri (1996:19); for a more extensive discussion, see Zuliani (2009:44-46, and 52-54 for the devices used by De André to avoid this problem). 
that the public for this music places it at the highest level in their cultural hierarchy.

Furthermore, literature provides another parallel to these developments. Indeed, from the end of the $18^{\text {th }}$ century, the disruption of traditional structures prompted the evolution of modern Italian poetry. ${ }^{33}$ This evolution took place not only as a formal or structural change, but also as an aesthetic one. In fact, the Romantic era of the $19^{\text {th }}$ century created predominantly lyric poetry that is often perceived, at least theoretically, as: "the free and true expression of any living and deeply-felt sensation." ${ }^{34}$ An unavoidable consequence of this new aesthetic was that poets endeavoured to break the bonds of tradition, which curbed the development of language in various ways. While these literary developments took place centuries ago, popular culture, as usual, has arrived much later. Indeed, among the singers who participate in the highest level of song writing, some may often resemble the $19^{\text {th }}$-century French poet maudit. For such a singer, it is often of fundamental importance to distinguish oneself from the cultural associations of trivial pop-songs.

In the last few decades, Anglo-American rock and pop music has often followed the same trend. If one looks, for instance, at a Pearl Jam song, like Alive, Jeremy, or Even flow, one may note a preference for looser structures, as well as run-on sentences and asymmetrical patterns. And yet, the musical phrases in these songs can still develop freely and end on an accented note. Every language has its own particular needs. The strongest linguistic limitations in English lines stem from the difficulty in creating rhymes, and the most noticeable trend is, thus, the renunciation of regular rhyme schemes. In Italian alternative music, the process has to go further because the aim is to dispose of fixed cadences and monotonous rhythms, which hinder the normal texture of the Italian language and are characteristic features of the more trivial canzonette.

33 In Italy, the evolution began with Ugo Foscolo, who used an innovative syntax inside traditional forms like the sonetto, and Giacomo Leopardi, who relinquished the traditional metric forms of lyric poetry.

34 This is a quotation from Leopardi's Zibaldone (Pacella 1991,2:2351): lyric poetry is the "espressione libera e schietta di qualunque affetto vivo e ben sentito dell'uomo." 
Consequently, these new directions in contemporary Italian song lyrics must be to a certain extent polygenetic. In fact, similar lyrics from the past decades can always be found on the edge of the mainstream. Some possible examples are songs like Luigi Tenco's Cara maestra (1962), Giovanna Marini's I treni per Reggio Calabria (1975), or the Stormy Six's Dante di Nanni (1975). While the musical style of these less fervently performed songs is obviously different, they nevertheless constitute examples in which the rhythm of the Italian language prevails. It is impossible to foresee if contemporary aesthetic taste will finally let this style of lyrics into the mainstream, however. After all, these latest trends are just another testimony to a long-standing conflict in the history of Italian song: the inevitable battle for supremacy between the prosody of the poetic text (and of the Italian language) and the unyielding rhythm of the musical line.

\section{References}

Antonelli, G. (2005) "Il complesso pop. Su una tendenza recente dei testi di canzone". Storia della lingua italiana e storia della musica. Atti del IV Convegno ASLI, 219-232, Firenze.

Antonelli, G. (2010) Ma cosa vuoi che sia una canzone. Mezzo secolo di italiano cantato. Bologna.

Baffa, C., ed. (2011) Cosa volete sentire. Compilation di racconti di cantautori italiani. Roma.

Beltrami, P.G. (2011) [1991] La metrica italiana. Bologna.

Bertinetto, P.M. (1981) Strutture prosodiche dell'italiano. Firenze.

Coveri, L. (1996) "Per una storia linguistica della canzone italiana". In: L. Coveri (ed.), Parole in musica: Lingua e poesia nella canzone d'autore italiana. Saggi critici e antologia di testi di cantautori italiani, nuova edizione aggiornata, 13-24, Novara.

Fabbri, P. (2007) Metro e canto nell'opera italiana. Torino.

Gianattasio, F. (1998) [1992] Il concetto di musica. Contributi e prospettive della ricerca etnomusicologia. Roma. 
Giovannetti, P. (2009) "Il verso di canzone: una neometrica dal basso?". Il suono e l'inchiostro. Cantautori, saggisti, poeti a confronto, 151-159. Milano.

Giovannetti, P. (2011) “Canzone”. In: A. Afribo / E. Zinato (eds.), Modernità italiana. Cultura, lingua e letteratura dagli anni Settanta ad oggi, 261287, Roma.

Gronda, G. / P. Fabbri, eds. (1997) Libretti d'opera italiani: dal Seicento al Novecento. Milano.

La Via, S. (2006) Poesia per musica e musica per poesia. Dai trovatori a Paolo Conte. Roma.

Pacella, G., ed. (1991) Giacomo Leopardi. Zibaldone. 3 vols. Milano.

Menichetti, A. (1993) Metrica italiana. Fondamenti metrici, prosodia, rima. Padova.

Menichetti, A. (2006) Saggi metrici, Firenze.

Proto, T. / F. Dell (2013) "The structure of metrical patterns in tunes and in literary verse. Evidence from discrepancies between musical and linguistic rhythm in Italian songs". Probus 25. 105-138.

Zucco, R. (2001) Istituti metrici del Settecento: l'ode e la canzonetta. Genova. Zuliani, L. (2009) Poesia e versi per musica. L'evoluzione dei metri italiani. Bologna. 
